\title{
Green Coffee Extract Modifies Body Weight, Serum Lipids and TNF-a in High-Fat Diet-Induced Obese Rats
}

Cimi Ilmiawati ( $D$ ilmiawati@med.unand.ac.id)

Andalas University Faculty of Medicine https://orcid.org/0000-0001-5743-3331

Fajar Fitri

Faculty of Medicine Andalas University

\section{Zelly Dia Rofinda}

Faculty of Medicine, Andalas University

\section{Mohamad Reza}

Faculty of Medicine, Andalas University

\section{Research note}

Keywords: green coffee extract, lipid profile, obesity, TNF-a

Posted Date: April 2nd, 2020

DOI: https://doi.org/10.21203/rs.2.18429/v2

License: (a) (i) This work is licensed under a Creative Commons Attribution 4.0 International License.

Read Full License

Version of Record: A version of this preprint was published at BMC Research Notes on April 10th, 2020.

See the published version at https://doi.org/10.1186/s13104-020-05052-y. 


\section{Abstract}

Objective: Currently, there are many efforts to find functional nutrients for obesity management, and the green coffee extract is a potential candidate. This study aimed to examine the effect of the green coffee extract on body weight, serum lipids, and TNF-a level in obese rats. Results: Administration of green coffee extract to high-fat diet-induced male Wistar rats (Rattus norvegicus) reduced body weight, total serum cholesterol, and triglyceride at the dose of 10,20 , and $40 \mathrm{mg} / \mathrm{kg} \mathrm{BW} /$ day; lowered LDL-cholesterol at the treatment of $20 \mathrm{mg} / \mathrm{kg} \mathrm{BW} /$ day $(\mathrm{p}<0.05)$. The effective dose to decrease serum TNF-a level was 40 $\mathrm{mg} / \mathrm{kg} \mathrm{BW} /$ day, while the effective dose to improve the lipid profile was $10 \mathrm{mg} / \mathrm{kg} \mathrm{BW/day}$. These results supported the potential use of green coffee extract as a functional nutrient in the management of obesity

\section{Introduction}

Obesity is a universal public health problem characterized by increased adiposity, particularly in the abdominal region, which associated with increased cholesterol levels. Obesity often presents with dyslipidemia, where there is a high level of triglycerides (TGs), low-density lipoprotein (LDL)-cholesterol, and a low level of high-density lipoprotein (HDL)-cholesterol [1, 2]. As a chronic inflammatory condition, serum TNF-a level is elevated in obesity [3]. Obese rats have a $22 \%$ higher TNF-a level compare to normoweight rats [4]. Obese subjects are known to produce excess TNF-a in adipose and muscle tissues [5], where it plays a role in insulin resistance [6].

An epidemiological study showed that drinking coffee can have a weight-loss effect due to its chlorogenic acid content [7]. Recently, there is an increase in a study examining the impact of green coffee extract (GCE) on obesity. GCE contains chlorogenic acid (CGA), a phenolic compound with antioxidant property. CGA increases lipid metabolism, decreases triglyceride and cholesterol levels, and increases plasma adiponectin level [8]. Moreover, GCE has been shown to reduce visceral fat mass [9] significantly. In in vivo tudies in mice and rats, chlorogenic acid has been shown to regulate glucose and lipid metabolism, increased insulin sensitivity, and improved obesity [10]. Animal studies examining the effect of GCE on body weight, showed conflicting results [7, 11, 14]. Furthermore, the effect of GCE on serum lipid profile was previously seen in rodents administered relatively high doses of GCE or CGA [7, 14]. The objectives of the current study were to observe the impact of GCE on body weight, serum lipid profile, and serum TNF-a of obese rats by administrating dosing regimen lower than previously published studies.

\section{Methods}

\section{Animals and diets}

This study was approved by the Ethics Committee of the Faculty of Medicine Andalas University (No.381/KEP/FK/2017) and was conducted according to the institutional guidelines for animal research. Eight-week-old male Wistar rats (Rattus norvegicus) weighed around $200 \mathrm{~g}$ were obtained from an 
experimental animal breeding company (Tiput Abadi Jaya Peternakan Hewan Uji, Yogyakarta, Indonesia). They were acclimatized while fed with standard chow ad libitum. The rats were housed in a $25^{\circ} \mathrm{C}$ room with $12 \mathrm{~h}$ light/dark cycle. After acclimatization, a group of male rats $(n=5)$ were randomly picked and assigned as the negative control group, which was fed standard chow ad libitum during the experiment, against which obesity induction was measured. A positive control group $(n=5)$ was fed standard chow ( $5 \%$ fat, $16 \%$ protein, crude fiber $8 \%$, ash content $10 \%$, water content $12 \%$ ) and cheddar cheese ad libitum (high-fat diet) throughout the experiment. Other groups of rats (the treatment groups, $n=15$ ) were fed with standard chow supplemented with cheddar cheese to induce obesity for eight weeks. The cheddar cheese contained $33.1 \%$ fat, $25 \%$ protein, $1.3 \%$ carbohydrate (wt/wt), and energy $4 \mathrm{kcal} / \mathrm{g}$. The cheese was given along with the standard chow in the same container, and the rats had free access to their diet. We did not observe a preference for one of the diets. Obesity induction was considered successful when there is a significant weight gain compared to the standard diet group. Treatment groups were separated into three weight-matched groups (each $\mathrm{n}=5$ ) and were given a high-fat diet and GCE at 10, 20, and $40 \mathrm{mg} / \mathrm{kg}$ body weight (BW)/day, respectively, for 13 days [7]. The GCE doses were lower than used in previous studies [7, 14]. The outcomes of the treatment were body weight, serum lipids levels, and serum TNF- a level.

\section{GCE}

GCE used in this study was the commercial product of Hendel Exitox Green Coffee Bean ${ }^{\circledR}$ (Jakarta, Indonesia). Each capsule of this product contains $500 \mathrm{mg}$ of GCE with $20.5-56.5 \mathrm{mg}$ of CGA. The GCE was administered orally by gavage at the experimental dose of 10,20 , and $40 \mathrm{mg} / \mathrm{kg} \mathrm{BW}$ per day.

\section{Serum lipids and TNF-a analysis}

After 13 days of treatment with GCE, on day 14, rats were anesthetized with diethyl ether at a concentration of $1.9 \%$, and blood was drawn from the orbital sinus for measurement of serum lipids (total cholesterol, triglycerides, LDL-cholesterol, HDL-cholesterol) and TNF-a. Blood samples were transferred into a tube and were centrifuged to separate the sera. Sera were analyzed at the Laboratory of Biochemistry Faculty of Medicine Andalas University according to standard methods. TNF-a in serum samples were analyzed at the Laboratory of Biomedicine Faculty of Medicine Andalas University by using ELISA kit (Rat TNF-a ELISA Kit; Elabscience). Rats were sacrificed by cervical dislocation.

\section{Statistical analysis}

Data were checked for normal distribution by Shapiro-Wilk test. Differences in 'groups' means were analyzed by One Way ANOVA, followed by Bonferroni's post-hoc test. Data were considered statistically significant when $\mathrm{p}$-value $<0.05$.

\section{Results}

All animals $(n=25)$ were healthy throughout the experiment. First, we assessed the success of high-fat diet-induced obesity by comparing rats fed standard chow $(n=5$; negative control) with those fed standard 
chow plus cheese ( $n=20$; induced obesity group). Afterward, the induced obesity group was randomly separated into four groups (each $n=5$ ) and subjected to GCE treatments and further analysis.

\section{The effect of GCE on body weight of high-fat diet-induced obese rats}

Animals fed a high-fat diet for eight weeks; all showed significantly increased body weight (Figure 1A). Treatment with GCE for various doses (10, 20, and $40 \mathrm{mg} / \mathrm{kg} \mathrm{BW} /$ day) for 13 days resulted in a statistically significant weight loss compared to the control group (Bonferroni test; $p<0.001$ ) in a dosedependent manner (Figure 1A).

\section{The effect of GCE on serum TNF-a of high-fat diet-induced obese rats}

GCE treatment for 13 days on high-fat diet-induced obese male rats lowered TNF-a at the dose of 40 $\mathrm{mg} / \mathrm{kg} \mathrm{BW/day,} \mathrm{as} \mathrm{shown} \mathrm{in} \mathrm{Figure} \mathrm{1B} \mathrm{(Bonferroni} \mathrm{test;} \mathrm{p}<0.05)$.

\section{The effect of GCE on serum lipids of high-fat diet-induced obese rats}

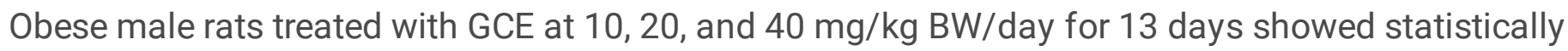
significant lower serum total cholesterol and triglycerides levels compared to the control group (Figure 2A and Figure 2B, respectively). Treatment with GCE at the dose of 20 and $40 \mathrm{mg} / \mathrm{kg} \mathrm{BW} /$ day also resulted in statistically significantly lower serum LDL-cholesterol levels (Figure 3A). GCE treatment showed no effect on serum HDL-cholesterol levels except at the dose of $40 \mathrm{mg} / \mathrm{kg} \mathrm{BW} /$ day, where HDL-cholesterol level decrease slightly (Bonferroni test; $p<0.05$ ) (Figure 3B).

\section{Discussion}

\section{The effect of GCE on body weight}

This study shows that high-fat diet induces obesity in male rats, and the administration of low dose GCE resulted in weight loss in these obese rats. The chlorogenic acid content in GCE has been shown to have an anti-obesity effect $[7,8,12]$. Previously, a study in mice given high-fat diet and GCE at $100-200 \mathrm{mg} / \mathrm{kg}$ BW showed that GCE supplementation decreased body weight gain [13]. The observed anti-obesity effect may work by suppressing lipogenesis and stimulating lipolysis [13].

Our results are in line with previous findings in mice that showed chlorogenic acid affects obesity by lowering body fat accumulation through adipogenesis regulation [14]. Chlorogenic acid increases lipid metabolism in HFD-induced obese rats $[8,12]$. GCE significantly reduced visceral fat accumulation, improved insulin resistance [9], and, when combined with energy-restricted diet, may lead to a significant reduction in body mass index, fat mass, and waist-hip ratio [15].

\section{The effect of GCE on lipid profile}

Antioxidant-rich foods known to lower serum cholesterol, LDL, and triglyceride levels. In this study, we found that low dose GCE administration lowers total serum cholesterol, triglycerides, and LDL- 
cholecsterol levels. GCE contains CGA, a potent antioxidant compound. It has been shown that CGA increases lipid metabolism, decreases triglyceride, and total cholesterol levels, possibly by its effect on fatty acid oxidation [16]. CGA in green coffee is an active compound capable of increasing metabolism rate [16], increasing fatty acid oxidation $[8,16]$, and decreasing hepatic triglyceride [7]. Apart from the CGA, the polyphenols in coffee also had a property in lowering visceral fat accumulation [18]. Unfortunately, we did not perform abdominal dissection to quantify visceral fat in this study.

In the current study, we found that the GCE has a negative effect on serum HDL levels. Serum HDL was lower in groups receiving $40 \mathrm{mg} / \mathrm{kg} \mathrm{BW/day} \mathrm{dose.} \mathrm{In} \mathrm{contrast,} \mathrm{those} \mathrm{receiving} \mathrm{lower} \mathrm{dose} \mathrm{(10} \mathrm{and} 20$ $\mathrm{mg} / \mathrm{kg} \mathrm{BW} /$ day) showed higher HDL levels despite not being statistically significant. This result is in line with a previous study were 28 days of chlorogenic acid intake lowered HDL level in male rats through regulation of hepatic PPARa expression $[16,19]$. These results might be explained by the possibility that CGA works specifically through the pro-atherogenic pathway of cholesterol metabolism. A clinical study in obese women aged 20-45 years showed that green coffee extract combined with calorie-restricted diet affected lipid metabolism through significant change in serum total cholesterol, LDL, and free fatty acid [15].

\section{The effect of GCE on TNF-a}

Our result showed that GCE decreased serum TNF-a statistically significantly in the group receiving 40 $\mathrm{mg} / \mathrm{kg} \mathrm{BW} /$ day dose. We showed that the effect on TNF-a is dose-dependent; however, the normal level of TNF-a $(10-100 \mathrm{pg} / \mathrm{ml})$ could not be attained with the given doses. A higher dose or more prolonged intake of GCE may result in a further decrease of TNF-a. It has been shown that CGA, the powerful antioxidant in GCE, attenuates serum levels of TNF-a in liver inflammation model [20]. CGA may downregulate the activation of NF-kB, which leads to a lower level of ROS that inhibits the production of the proinflammatory cytokine, like TNF-a [21].

\section{Conclusion}

Our study confirmed that low dose GCE has a beneficial effect on body weight and lowers total serum cholesterol, triglyceride, LDL, and TNF-a levels in high-fat diet-induced obese rats. Our findings strengthen the scientific evidence on the property of GCE in the management of obesity and hyperlipidemia.

\section{LIMITATIONS}

- Abdominal fat was not weighed for obesity assessment

- The number of animals in each treatment group was small

\section{Abbreviations}

ANOVA = analysis of variance 
$\mathrm{BW}=$ body weight

CGA $=$ chlorogenic acid

ELISA = enzyme-linked immunosorbent assay

$\mathrm{GCE}=$ green coffee extract

$\mathrm{HDL}=$ high-density lipoprotein

HFD = high-fat diet

LDL = low-density lipoprotein

$\mathrm{NF}-\mathrm{kB}=$ nuclear factor-kappa $\mathrm{B}$

ROS $=$ reactive oxygen species

$\mathrm{TG}=$ triglyceride

TNF- $a=$ tumor necrosis factor-alpha

\section{Declarations}

\section{Ethics approval and consent to participate}

The Ethics Committee of the Faculty of Medicine, Andalas University, approved all procedures involving laboratory animals (No. 381/KEP/FK/2017).

\section{Consent for publication}

Not applicable.

\section{Availability of data and materials}

Data from this study are available from $\mathrm{Cl}$ on a reasonable request.

\section{Competing interests}

None of the authors had any personal or financial conflict of interest.

\section{Funding}

None.

\section{Authors' contributions}


$\mathrm{Cl}$ was responsible for designing the study, giving input on data analysis, improved the manuscript writing, and overall management. FF carried out the data collection, data analysis, and wrote the manuscript. ZDR provided suggestions for the study design, data analysis, and manuscript writing. MR provided insightful feedback on data analysis and manuscript writing. All authors read and approved the final manuscript.

\section{Acknowledgments}

The authors would like to acknowledge the staff at the Laboratory of Biochemistry Faculty of Medicine Andalas University for their technical support during the study.

\section{References}

1. Ebbert JO \& Jensen MD. Fat depots, free fatty acids, and dyslipidemia. Nutrients. 2013;5(2):498-508.

2. Enomoto M, Adachi $H$, Hirai Y, Fukami A, Satoh A, Otsuka M, et al. LDL-C/HDL-C ratio predicts carotid intima-media thickness progression better than HDL-C or LDL-C alone. J Lipids. 2011;549137.

3. Bhushan B, Guleria R, Misra A, Luthra K, Vikram NK. TNF-alpha gene polymorphism and TNF-alpha levels in obese Asian Indians with obstructive sleep apnea. Respir Med. 2009;103: 386-92.

4. Uysal KT, Wiesbrock SM, Marino MW, Hotamisligil GS. Protection from obesity-induced insulin resistance in mice lacking TNF-a function. Nature. 1997;389: 610-4.

5. Arslan K, Serdar Z \& Tokullugil HA. Multifunctional hormone: Leptin. University Medical Faculty Magazine. 2010;30(2): 113-8.

6. Xu H, Barnes GT, Yang Q, Tan G, Yang D, Chou CJ, et al. Chronic inflammation in fat plays a crucial role in the development of obesity-related insulin resistance. J Clin Invest. 2003;112(12): 1821-30.

7. Shimoda H, Seki E, Aitani M. Inhibitory effect of green coffee bean extract on fat accumulation and body weight gain in mice. BMC Complement Alternat Med. 2006;6: 9.

8. Cho AS, Jeon SM, Kim MJ, Yeo J, Seo K, Choi MS, et al. Chlorogenic acid exhibits anti-obesity property and improves lipid metabolism in high-fat diet-induced obese mice. Food Chem Toxicol. 2010;48:937- 43.

9. Song SJ, Choi S, Park T. Decaffeinated green coffee bean extract attenuates diet-induced obesity and insulin resistance in mice. Evid Based Complement Alternat Med. 2014.

http://dx.doi.org/10.1155/2014/718379

10. Meng S, Cao J, Feng Q, Peng J, Hu Y. Roles of chlorogenic acid on regulating glucose and lipids metabolism: a review. Evid Based Complement Alternat Med. 2013.

http://dx.doi.org/10.1155/2013/801457

11. Li Kwok Cheong JD, Croft KD, Henry PD, Matthews V, Hodgson JM, Ward NC. Green coffee polyphenols do not attenuate features of the metabolic syndrome and improve endothelial function in mice fed a high fat diet. Arch Biochem Biophys. 2014;559:46-52. 
12. Ong KW, Hsu A, Tan BK. Anti-diabetic and anti-lipidemic effects of chlorogenic acid are mediated by AMPK activation. Biochem Pharmacol. 2013;85:1341-51.

13. Tanaka K, Nishizono S, Tamaru S, Kondo M, Shimoda H, Tanaka J, et al. Anti-obesity and hypotriglyceridemic properties of coffee bean extract in SD rats. Food Sci Technol Res. 2009;15(2); 147-52.

14. Choi BK, Park SB, Lee DR, Lee HJ, Jin YY, Yang SH, Suh JW. Green coffee bean extract improves obesity by decreasing body fat in high-fat diet-induced obese mice. Asian Pac J Trop Med. 2016;9(7):635 - 43.

15. Haidari F, Samadi M, Mohammadshahi M, Jalali MT, Engali KA. Energy restriction combined with green coffee bean extract affects serum adipocytokines and the body composition in obese women. Asia Pac J Clin Nutr. 2017;26(6):1048-54.

16. Li SY, Chang CQ, Ma FY, Yu CL. Modulating effects of chlorogenic acid on lipids and glucose metabolism and expression of hepatic peroxisome proliferator-activated receptor in golden hamsters fed on high fat diet. Biomed Environ Sci. 2009;22(2):122-9.

17. Murase T, Misawa K, Minegishi Y, Aoki M, Ominami H, Suzuki Y, et al. Coffee polyphenols suppress diet-induced body fat accumulation by downregulating SREBP-1c and related molecules in C57BL/6J mice. Am J Physiol-Endocrinol Metab. 2011;300: E122-33.

18. Nagao T, Ochiai R, Watanabe T, Kataoka K, Komikado M, Tokimitsu I, et al. Visceral fat-reducing effect of continuous coffee beverage consumption in obese subjects. Jpn Pharmacol Ther. 2009;37(4): 333-44.

19. Wan CW, Wong CN, Pin WK, Wong MH, Kwok CY, Chan RY, et al. Chlorogenic acid exhibits cholesterol lowering and fatty liver attenuating properties by up-regulating the gene expression of PPAR-a in hypercholesterolemic rats induced with a high-cholesterol diet. Phytother Res. 2013;27(4):545-51.

20. Shi H, Dong L, Jiang J, Zhao J, Zhao G, Dang X, et al. Chlorogenic acid reduces liver inflammation and fibrosis through inhibition of toll-like receptor 4 signaling pathway. Toxicology. 2013;303:107114.

21. Liang $N \&$ Kitts DD. Role of chlorogenic acids in controlling oxidative and inflammatory stress conditions. Nutrients. 2016;8(1);16.

\section{Figures}




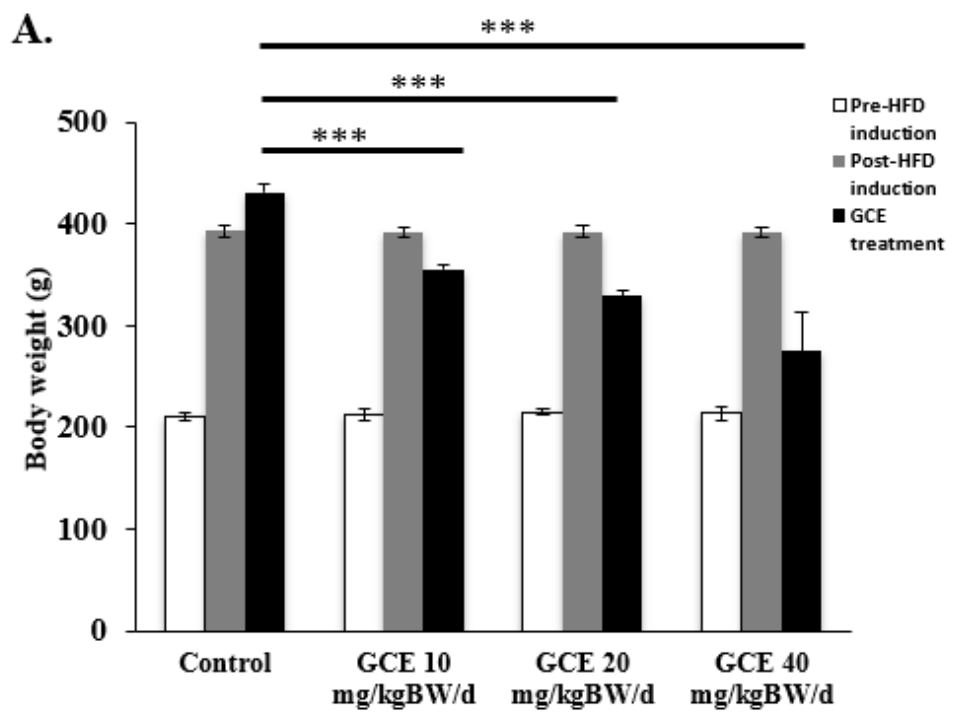

Group
B.

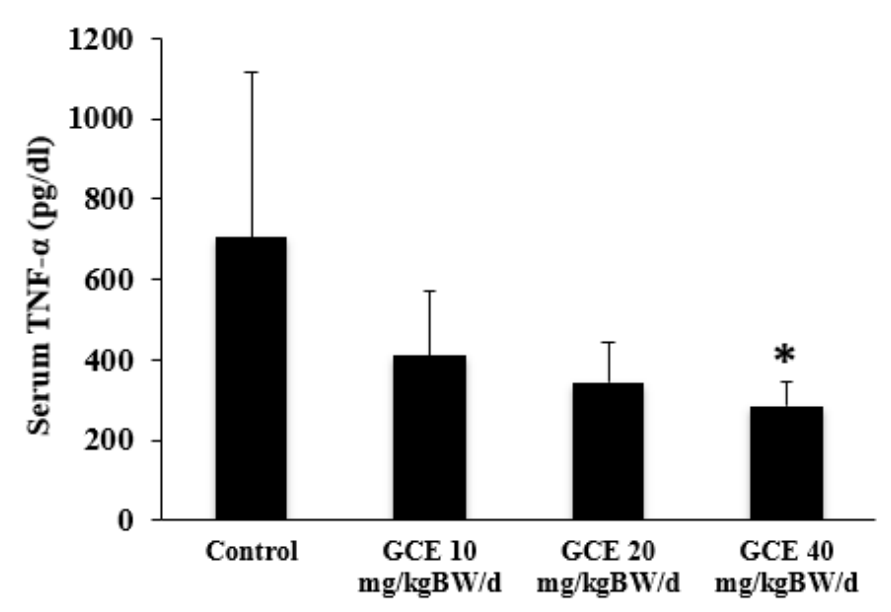

Group

\section{Figure 1}

A. The weight of male rats after a high fat diet (HFD) induction followed by $13 \mathrm{~d}$ of green coffee extract (GCE) treatment. The control group was fed HFD and placebo; treatment groups were fed HFD + GCE at 10,20 , and $40 \mathrm{mg} / \mathrm{kgBW} /$ day, respectively. ${ }^{* *} \mathrm{p}<0.001$ (Bonferroni test compared to control group). $\mathrm{B}$. Serum TNF-a levels ( $\mathrm{pg} / \mathrm{dl})$ in male rats after a high fat diet (HFD) induction followed by $13 \mathrm{~d}$ of green coffee extract (GCE) treatment. The control group was fed HFD and placebo; treatment groups were fed HFD + GCE at 10, 20, and $40 \mathrm{mg} / \mathrm{kgBW} /$ day, respectively. ${ }^{*} \mathrm{p}<0.05$ (Bonferroni test compared to control group).

A.

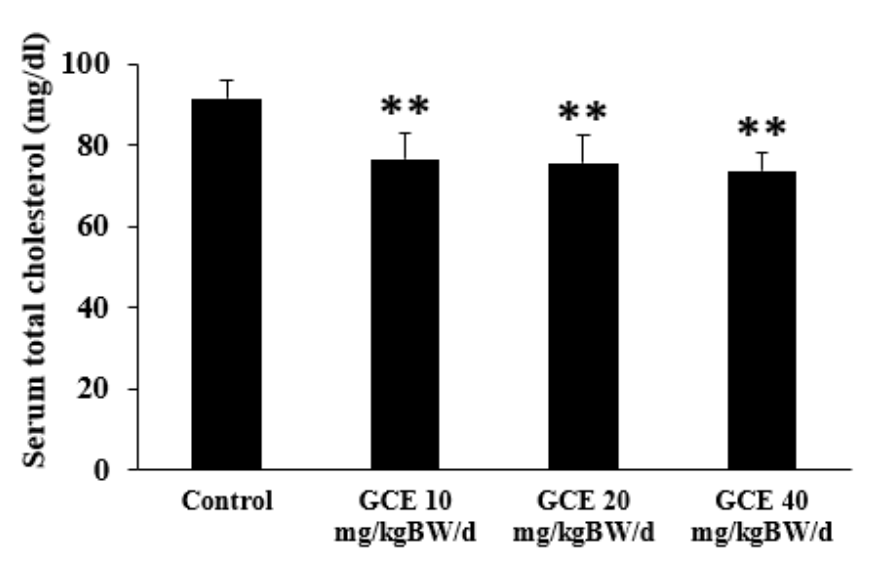

Group
B.

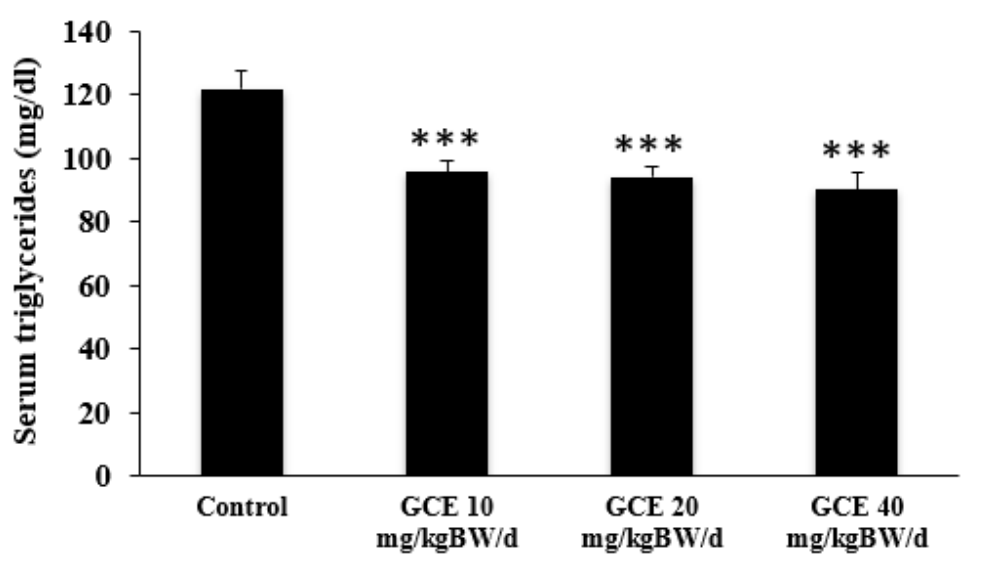

Group

Figure 2

A. Serum total cholesterol levels $(\mathrm{mg} / \mathrm{dl})$ in male rats after a high fat diet (HFD) induction followed by 13 d of green coffee extract (GCE) treatment. The control group was fed HFD and placebo; treatment groups 
were fed HFD + GCE at 10, 20, and $40 \mathrm{mg} / \mathrm{kgBW} /$ day, respectively. ${ }^{\star \star} \mathrm{p}<0.01$; ${ }^{* \star *} \mathrm{p}<0.001$ (Bonferroni test compared to control group). B. Serum triglycerides levels $(\mathrm{mg} / \mathrm{dl})$ in male rats after a high fat diet (HFD) induction followed by $13 \mathrm{~d}$ of green coffee extract (GCE) treatment. The control group was fed HFD and placebo; treatment groups were fed HFD + GCE at 10,20, and $40 \mathrm{mg} / \mathrm{kgBW} /$ day, respectively. ${ }^{\star \star \star} \mathrm{p}<0.001$ (Bonferroni test compared to control group).

A.

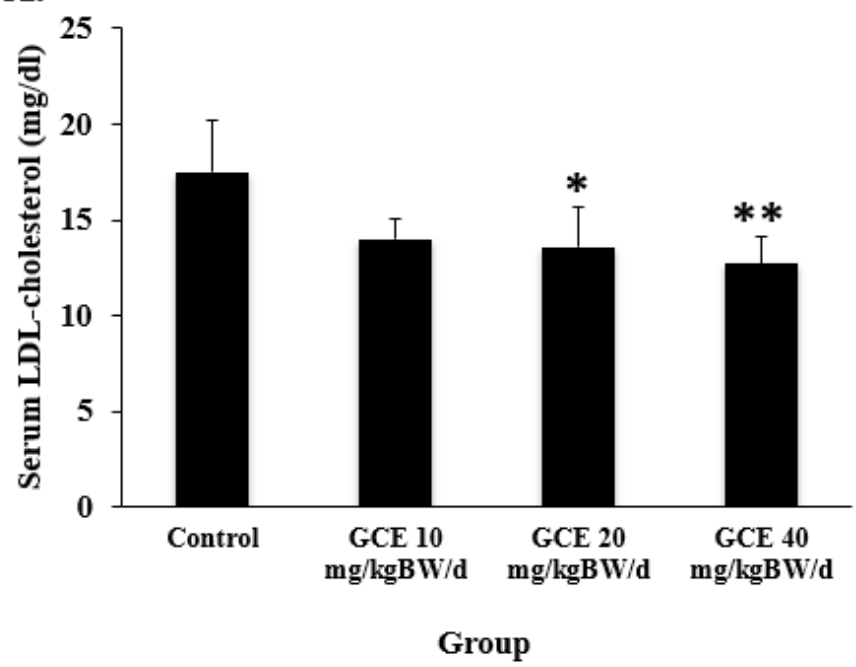

B.

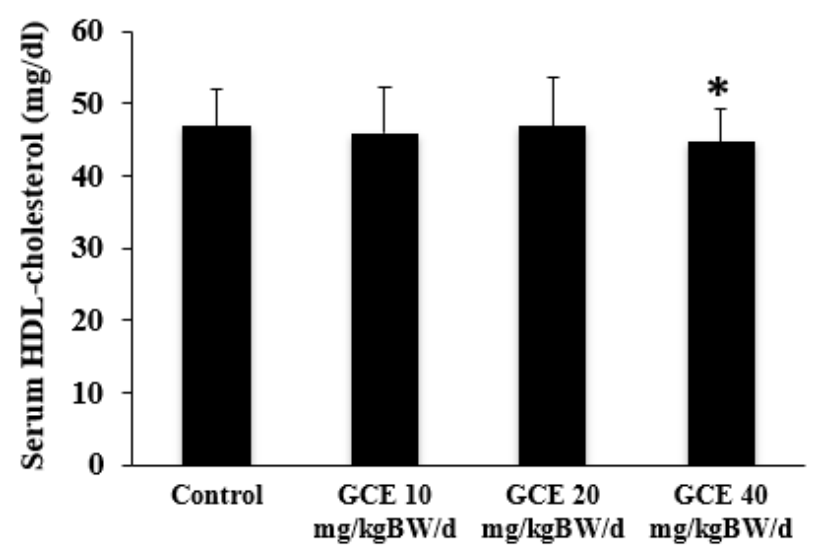

Group

\section{Figure 3}

A. Serum LDL-cholesterol levels $(\mathrm{mg} / \mathrm{dl})$ in male rats after a high fat diet (HFD) induction followed by 13 d of green coffee extract (GCE) treatment. The control group was fed HFD and placebo; treatment groups were fed HFD + GCE at 10, 20, and $40 \mathrm{mg} / \mathrm{kgBW} /$ day, respectively. ${ }^{*} \mathrm{p}<0.05$; ${ }^{* *} \mathrm{p}<0.01$ (Bonferroni test compared to control group). B. Serum HDL-cholesterol levels $(\mathrm{mg} / \mathrm{dl})$ in male rats after a high fat diet (HFD) induction followed by $13 \mathrm{~d}$ of green coffee extract (GCE) treatment. The control group was fed HFD and placebo; treatment groups were fed HFD + GCE at 10,20, and $40 \mathrm{mg} / \mathrm{kgBW} /$ day, respectively. ${ }^{*} \mathrm{p}<0.05$ (Bonferroni test compared to control group).

\section{Supplementary Files}

This is a list of supplementary files associated with this preprint. Click to download.

- SupplementalFigure.jpg

- AdherencetoARRIVEGuidelines.docx 